\title{
The Ideal Observer Meets The Ideal Consumer: Realism, Domestic Science, and Immigrant Foodways in Willa Cather's My Ántonia (1918)
}

\section{Stephanie Tsank}

\author{
I have never found any intellectual excitement any more in- \\ tense than I used to feel when I spent a morning with one of \\ those old [immigrant] women at her baking or butter making. \\ ... I always felt as if they told me so much more than they \\ said - as if I had actually got inside another person's skin \\ Willa Cather, Philadelphia Record ${ }^{1}$
}

In Cather's 1913 interview-the first full-length interview of her literary career-she cites what was for her the inspiration for much of her early fiction: immigrants and their distinct ethnic, cultural, and culinary identities. Yet she also reveals a potentially problematic desire to own and consume the immigrant body and experience. Cather, who grew up in Nebraska in the 1880s and befriended nearby immigrants from Bohemia and Scandinavia, wrote them into her Great Plains trilogy, beginning with O Pioneers! in 1913 and ending with My Ántonia in 1918 - a coming-of-age tale for white, native-born narrator Jim Burden and an exploration of his relationship with Ántonia Shimerda, his Bohemian immigrant neighbor. Cather's quotation is notable: it celebrates immigrants in the act of culinary creation, especially during a time when anxieties about mass immigration had reached their peak in the United States. At the same time, Cather's position in this scenario - she is, after all, white, middle class, and "native" - is one of authority and perhaps even possessiveness, espe- 
cially given her stated desire to inhabit the bodies of immigrants. When Cather reports that immigrant women reveal much more than they say, how does she know? How does observing immigrant women cook stimulate Cather intellectually? Does Cather's appreciation of immigrant culture and culinary aesthetics, in fact, tenuously cross over into an act of ownership?

These questions gesture toward the larger sociocultural atmosphere of the turn of the century to which Cather's work inevitably responded and was shaped. More specifically, reading food in My Ántonia helps illuminate the parallel traditions of literary realism and domestic science, two movements that enforced ethnographic containment and monitored consumption under the guise of promoting democratic principles and national unification. In this article, I will show how My Ántonia responds to and encapsulates these overlapping ideologies in two ways through its representation of immigrant foodways and scenes of eating. First, I argue, Cather supports the construction of the ideal observer by fixating on "foreign" foods through Jim Burden's narration and characterizes immigrants for the benefit of a white middle-class readership, both of which subtly perpetuate nativist ideologies. Second, food scenes in the narrative push against the concept of the ideal consumer by offering up more expansive ways to conceptualize identity through one's culinary practices and relationship to consumption.

Literary realism and domestic science, both of which emerged in the 1870s, defined themselves by an emphasis on accuracy through an adherence to verisimilitude in the former and to scientific principles in the latter. While realism participated in the trend of describing immigrants, or the lower classes, for a primarily white, middle-class readership and frequently relied on detached observation as a narrative method, the domestic scientists emphasized pragmatism and culinary homogeneity through the promotion of a carefully proscribed diet and advocated for a utilitarian, nutrition-centered approach to the act of consumption. Both movements sought to demarcate the boundaries of what should constitute the ideal American citizen and in doing so enforced a hierarchy of belonging and difference. Tracing the trajectory of literary realism alongside the ideological imperatives of the domestic scientists reveals both movements' participation in the construction of nationalism and nativism and, by proxy, highlights overlapping preoccupations about narrative and biological consumption. In other words, reading both movements together reveals an ongoing and interwoven anxiety about both what and how people read and ate. These anxieties helped shape what defined the ideal citizen and how that citizen functioned in society to ensure a carefully cultivated homogeneity that could then feed into a fixed and powerful national identity. Together, these two movements - both of which had lasting impacts well into the twentieth century-worked to shape the ideal citizen: the realist by shaping the ideal observer and the domestic scientist by presenting the ideal consumer.

Realism, championed by William Dean Howells, editor of the Atlantic Monthly from 1871 to 1881 , emerged in a post-Civil War America riddled with 
concerns about class structure, mass immigration, and racial purity. Realism's ideological and narrative techniques, as espoused by Howells, worked to soothe the fears of a fractured nation hoping to reconcile itself as whole. In 1891, Howells wrote in Criticism and Fiction - a treatise that, according to Michael Davitt Bell, made him "the most influential proponent of realism in America" — that "realism is nothing more and nothing less than the truthful treatment of material."'3 Railing against previous decades' preoccupation with sentimentalism and romance, Howells defined the ideal literary form as free of needless aesthetics and fanciful plot structure and instead as a vessel to faithfully depict everyday "reality" through the perspective of an impartial author aiming to accurately represent the world around them. This narrative lens was in part a means of controlling the relationship between subject and observer and, more so, of filtering the construction of the observed through a careful, discerning eye. Ensuring this relationship helped to safeguard a national body preoccupied with the threat of immigrant insurgence - a national body fixed in its status as native, elite, and white - despite Howells's positioning of realism as "democracy in literature."

The domestic science movement - initiated by a group of white, middleclass women who believed in the necessity of incorporating scientific principles into the homes of white, middle-class families — was similarly preoccupied with national identity and the principles of containment. The opening of the Boston Cooking School in 1879, founded by the Women's Educational Association of Boston, and the women who ran and taught at the institution over generations, such as Mary J. Lincoln, Fannie Farmer, and Maria Parloa, were instrumental in shaping the way that women comported themselves in the kitchen and in the home. At the heart of the movement, which began in the Northeast and quickly spread throughout the country, was the notion that women could maintain social order in the household and thus prepare their families to contribute to the nation's progress. Furthermore, many of the women who participated in the domestic science movement found it a pleasant and more appropriate alternative to participating in other types of reform movements, such as sanitation, abolition, and political corruption. This suggests that domestic science was itself a type of ideological reform and reinforces the notion that domestic scientists believed that, according to Laura Shapiro, "if they could reform American eating habits, they could reform Americans." 5

Indeed, Cather's suggestion in 1913 that she could get inside the skins of immigrant women through the simple act of observing them in the act of cooking brings up a whole host of tensions, from questions about intersubjectivity to the relationship between high and low culture, native versus immigrant, and so on. But perhaps less obvious is the way in which Cather's quotation reveals how the act of storytelling intersects with the act of cooking and how the stories - and cuisines - we craft and consume simultaneously construct reality and shape our perceptions of the world. 


\section{Containing the Mind}

We lose our first keen relish for literature just as we lose it for ice-cream and confectionary. The taste grows older, wiser, and more subdued.

Cather, "William Dean Howells",

In Cather's 1895 review of Howells's My Literary Passions, several things stand out: her comparison between reading and eating, her identification of both literature and food as sensory objects from which to derive pleasure, and her mention of sweets. Cather's commentary is unsurprising given the pervasiveness of the "reading/eating" metaphor in mid-nineteenth-century guidebooks and periodicals. As Cree LaFavour points out, "The pleasure of a novel that is difficult to put down was akin to the sweets that women and children gobbled as they turned the pages in a kind of rapturous self-indulgence." " In other words, in the mid-nineteenth century, the pleasures of reading and eating were dually perceived as dangerous activities; when left uncontrolled, they were thought to threaten the physical and mental health of white, middle-class women and, by proxy, the health of their families and the nation. These restrictive attitudes about consumption persisted into the later decades of the century as both the realists and the domestic scientists sought to refashion the American body on individual and national scales by attempting to control how the public consumed the world around them.

Howells's many critical treatises and editorials set precise boundaries for what should ideally make up a cohesive and valuable American literature in addition to carving out a distinct relationship between writer, subject, and style (or lack thereof). In part a reaction to the idleness and frivolousness he associated with romance, Howells sought to reformulate reading as a productive exercise by reshaping the content of the ideal literary text and the lens through which it was filtered. Influenced by new technologies of reproduction and an increased social focus on observation and exactness, as Daniel Borus notes, realists "took to empirical observation with unprecedented enthusiasm," ${ }^{8}$ using these techniques to construct the ideal observer - a detached yet "truthful" narrator aiming to further the nation's democratic project by depicting life "as is." Howells expounds on these ideals in Criticism and Fiction (1891), urging new writers and artists to rely entirely on the authority of their own senses and observations rather than idealizing and attempting to imitate the literary works of already established writers. ${ }^{9}$

Howells further frames the act of writing as a moral imperative-albeit one that is carefully controlled by individuals who have been granted authority by the publishing industry to dispense their views. According to Amy Kaplan, realists not only sought to determine the ideal text but also, through their writing, attempted to re-create their social environment. Writers' imperatives to re-create their surroundings stemmed from anxieties about perceived social 
problems and major changes in society, such as rapid industrialization, mass immigration, and the subtle shifting of social classes. Although Howells' efforts to reformulate literature appeared inclusive, as he hoped that realism would provide a platform for writers to extend representation to formerly obscured communities, realist texts primarily served to comfort a white, middle-class readership anxious about the rapid insurgence of nonwhite immigrants into American society. ${ }^{10}$

Howells and Cather shared a preoccupation with how readers consumed literature in that they were skeptical of leisure reading and popular fiction, the latter of which boomed in the late nineteenth-century literary marketplace. Cather did not want My Ántonia to be published in paperback or to be optioned for film, as she considered consumers of these mediums to be of a "lower social and cultural class." 11 Instead, Cather actively fought her first publisher, Houghton Mifflin, to continue to publish hardback copies of her book, which only a certain class of individuals could afford. Howells, similarly, was opposed to the mindless consumption of literature that romance seemed to breed; as Kaplan explains, "Howells viewed reading as a productive exercise, and promoted literary engagement as hard work as opposed to "idle consumption." In his treatises, Howells suggested that the result of this specific type of reading-that which undergirded realism's ideological mission —-would be a democratic society in which all the nation's people could finally achieve proper representation. Ultimately, however, the narrative structure characteristic of realism worked primarily to confirm the classist, nativist, and ethnographically secure identity of the group to which the author wrote and typically belonged.

\section{Containing the Body}

The domestic scientists' approach to consumption promoted a similarly restrictive path for eaters and consumers under the guise of national unification and progress. In developing a scientific, nutrition-based agenda that centered on an ideology of containment - containing ingredients, recipes, and one's emotional response to eating - the domestic scientists aimed to contain and, perhaps, remake the body by determining what entered it and how. Propelled by exactitude in measurement and procedure, recipe design for the domestic scientists was about composure and control; for example, it was common for cooking school courses and cookbooks to instruct women to arrange the ingredients of a salad - and other types of dishes - within acceptable physical boundaries, such as walled in by four crackers or stuffed into the peel of a banana. These types of recipes promoted eating as an act of practical nourishment rather than a process of enjoyment and gustatory pleasure; in other words, nutrition trumped taste. Paralleling Howells's preoccupation with romance as a breeding ground for dangerously idle consumption, so too did the domestic scientists push against the notion of eating simply for pleasure and without proper regard to scientific principles and nutritional value. 
Katharina Vester asserts that "food advice in cookbooks and magazines has traditionally told readers not only how to eat well, but how to be Americans, how to be members of the middle class, how to perform as heterosexual men and women." 12 Indeed, cookbooks written by prominent members of the domestic science movement in the late nineteenth century, such as Mary J. Lincoln and her successor Fannie Farmer, subtly reinforce traditional gender roles and heteronormativity, aspire to shape national identity through the family unit, and assume that readers already belong to or aspire to belong to the middle class. Lincoln's Mrs. Lincoln's Boston Cook Book: What to Do And What Not to Do in Cooking, first published in 1884, is a comprehensive, detailed, and restrictive account of what to do in the kitchen. In her preface, Lincoln claims that she will teach homemakers "just how to hold your bowl and spoon, to use your hands, to regulate your stove, to wash your dishes; and just how not to fall into the errors into which so many have stumbled before you." 13 The emphases on "how" and "how not" and the addition of "just" highlight the precision and specificity offered by the cookbook and predicted by its title.

Farmer's revision of Lincoln's cookbook, The Boston Cooking-School Cook Book (1896), is, like its predecessor, over 500 pages long. Strikingly, Farmer's table of contents is much more exhaustive, where recipes with the same ingredients are listed with slight alterations, such as "Scrambled Eggs," followed by "Scrambled Eggs with Tomato Sauce," followed by "Scrambled Eggs with Anchovy Toast."14 Other foods are partitioned via cooking methods with minor variations, such as "Plain Lobster," "Fried Lobster," "Buttered Lobster," "Scalloped Lobster," "Curried Lobster," and so on. ${ }^{15}$ Farmer's cookbook also includes guidelines for basic tasks; for example, a recipe for "Dry Toast" requires the cutting of stale bread into "one-fourth inch slices" and the browning of the bread over coals. Farmer then writes, "Toast may be buttered at table or before sending to table," 16 accounting for each possible movement that the cook makes. Finally, Chapter 38, titled "Helpful Hints to the Young Housekeeper," not only lists tips for the kitchen, such as "To Chop Parsley" or "To Cream Butter," but also provides instructions for household chores, such as "To Remove White Spots from Furniture" and "To Wash Mirrors and Windows," 17 thereby pairing cooking techniques with other domestic practices.

Farmer, who took Lincoln's place as head of the Boston Cooking School in 1896, marked a slight departure from the rigidity and dryness of previous approaches, routinely describing dishes as “' tasty,' 'delicious,' 'appetizing,' and very often 'delightful." "18 Yet, despite Farmer's updated approach to consumption as a potentially pleasurable enterprise, Farmer's cooking instructions leave little to the imagination and rely entirely on precision, measurement, and the application of scientific principles to culinary preparations. Each action-from slicing toast to washing mirrors - is planned and decided in advance by the directive of the cookbook to suggest how best to maintain order and expediency in the home. 
Shapiro explains the domestic scientists' philosophy as this: "If the home were made a more businesslike place, if husbands were fed and children raised according to scientific principles, if purity and fresh air reached every corner of the house - then, at last, the nation's homes would be adequate to nurture its greatness." ${ }^{19}$ Put differently, if women cut their toast slices in fourths as Farmer recommended to ensure that their husbands and children consumed precise ingredients in precise quantities for proper nourishment, perhaps families would be better prepared to continue to uphold the uniformly "correct" ideals of family and nation. Having been properly fed, these "ideal" citizens would then be prepared to continue to serve as model individuals upholding a model nation.

In the early decades of the twentieth century, the domestic science movement developed into what is now known as home economics. The first wave of home economists was influential in shaping America's developing consumer culture and were simultaneously preoccupied with preserving nineteenth-century ideas about morality. Carolyn M. Goldstein writes that despite variations among individual teachers and intended audiences, "the quantifiable aspects of foods and their constituent parts took precedence over taste and pleasure for most home economists. ${ }^{20}$ Once again, emphasis remained on utility over pleasure, on use value versus cultural affect. Likewise, the imperative of the domestic scientists and home economists to consume more efficiently and uniformly was supported by advancements in industrialization and food production that occurred throughout the late nineteenth and early twentieth centuries on a national scale. The expansion of railway networks, improvements in refrigeration technology, and the corporatization of food production all contributed to a more centralized and homogenized cuisine. Unsurprisingly, many food reformers valued processed ingredients because of their supposed superior cleanliness and uniformity in both packaging and taste. ${ }^{21}$

The domestic scientists believed that what and how you ate would determine your social environment and encouraged the process of Americanization by extending cooking classes to immigrants and shaping ideas about proper diet in schools. In fact, women reformers counted on the desire of immigrant children to conform to their surroundings and used food as a means of supporting this transition. ${ }^{22}$ Later, during World War I, home economists collaborated with governmental agencies to pursue an agenda of "rational consumption," which helped to reduce the ingestion of specific foods - for example, wheat, meat, and sugar - to aid in wartime conservation. The home economists' success on this front was an ideological triumph, as it helped further link food consumption to patriotism, which, according to Goldstein, was "part of a larger mission to shape the culture of the emerging middle class through a focus on the standard of living of individual homes and families." ${ }^{23}$

These examples illustrate that both home economists and domestic scientists were fueled by the desire to monitor and control consumption as a means of structuring individual identities as well as the family unit. In promoting a nutrition-based relationship to food — one that did not support culturally diverse 
cuisines and eating habits - these groups simultaneously championed assimilation and Americanization. Ultimately, by controlling consumption, one of the most fundamental aspects of human existence, the domestic scientists and early home economists suggested that those who did not conform to specific diets could be barred from participating in the nation's progress. The imperatives of realism as espoused by Howells hinged on similar principles of containment through the practices of narrative and social control. Howells's restructuring of the process of reading as a productive, democratic endeavor meant that some readers would have been inevitably considered "undemocratic" based on their decision to consume literature in "unproductive" ways. Ultimately, Howells's reformulation of American literature not only aimed to change the way that individuals consumed literature but also sought to refashion the American body by writing a new body into being. Cather, of course, was not immune to either of these literary and culinary developments.

\section{The Ideal Observer}

That she was eventually to be called a classicist, a Jamesian sophisticate, and the reserved stylist of The Novel Démeublé, may be one of the great jokes of literary criticism. The young Willa Cather ... was primarily a romantic and a primitive.

Bernice Slote, The Kingdom of $\mathrm{Art}^{24}$

Slote is not alone in her confident classification of Cather within a specific mode or genre; others have attempted to position Cather as a modernist, seeing in her style a certain element of "radicalness" or pairing her with writers such as Virginia Woolf. ${ }^{25}$ Yet others, such as John J. Murphy and Janis P. Stout, have sought in Cather's oeuvre examples of her employment of realism, arguing for the presence of a Howellsian "antiliterary" strain or noting the depth of her "visual accuracy" and investment in depicting everyday life, respectively. Nonetheless, despite attempts at classification, many critics have also noted the futility of containing Cather's aesthetic to any one genre; an examination of her nonfiction and fiction writings, at the very least, makes abundantly clear that Cather's critical proclamations and novelistic endeavors were not always in line. ${ }^{26}$

In this article, I do not attempt to categorize Cather within any particular mode or genre; however, I argue for the value of reading Cather in relation to genre, specifically realism. In her monograph Reading for Realism, Nancy Glazener quotes June Howard, who reminds us that "genre inevitably enters into every work but no work is contained by genre." ${ }^{27}$ Howard's credo is useful for thinking about Cather's expansive oeuvre - a text like My Ántonia, for example, is testament to the fact that a novel can engage with the genre conventions of its day without being defined by them. At once a pastoral ode, a nostalgic and spontaneous outpouring of emotional energy, yet also an incisive commen- 
tary about immigrant displacement and an inevitable meditation on narrative authority, My Ántonia seems precisely to elude such attempts at containment.

Certainly, Cather's own writing was not immune to the literary techniques and philosophies associated with realism. As some critics have argued, even though Cather openly protests realism in her well-known aesthetic treatise "The Novel Démeublé" (1922), certain works of hers display an adherence to realist and, in other cases, naturalist principles. ${ }^{28}$ Indeed, despite Cather's critical attitude toward realism in her early years and throughout her life, the contradictions of her relationship to realism are evident and at times ironic. ${ }^{29}$ For example, Cather confidently states in the same treatise, "One does not wish the egg one eats for breakfast, or the morning paper, to be made of the stuff of immortality." ${ }^{30}$ Here, leveling a critique of Howellsian realism, Cather argues that one's breakfast must not be treated as though it automatically has some sort of political or social meaning simply because it represents the life of ordinary people. ${ }^{31}$ Yet what Cather's own inevitably limited and privileged Western perspective misses and what Cather scholarship has not yet fully explored is that Cather does immortalize the egg; or, rather, in the case of My Antonia, she immortalizes the mushroom and the melon. Cather often depicts foods that are ordinary for immigrants as though they are extraordinary, imbuing them, for the benefit of her white, middle-class readership, with sensual and sensationalistic affect.

Inherent in Howells's approach is a rejection of "literariness," or the elaborate crafting of material to fit a specified literary mold. Cather's narrator, Jim Burden, follows Howells's recommendation by enacting the opposite of literariness - his manuscript is not carefully crafted or influenced by any other outside source; it is, rather, an outpouring of emotion via observation and firsthand experience. Moreover, because of Jim's white male authority, the novel itself is established as a physical manuscript that essentially seals within its pages a record of early Nebraskan pioneer life. ${ }^{32}$ Although some critics have attempted to classify My Ántonia as romance due to its narrative structure, I contend that Jim's method of composition and the way that he approaches his subject are in fact reminiscent of Howells's stipulations in his early realist treatises, and Jim's ability to create such a manuscript is tied to the ease with which he can move about the world, in contrast to Ántonia and the novel's other immigrants. ${ }^{33}$ Although Jim is hugely shaped by his experiences with Ántonia and the other immigrant homesteaders, his narration is also steeped in the convenience of observation brought on by assured distance. Jim is the "ideal" observer in that he is impacted by Ántonia's presence, but he has the option to withdraw from her gaze at any time and, in fact, does for several decades. Even though there exist scenes where immigrant identities and experiences are foregrounded, Jim's narrative authority remains front and center in My Ántonia's content and construction.

Despite the novel's attempt to illustrate a pluralist society where different cultures can exist comfortably alongside one another without the threat of assimilation, My Ántonia precisely overlooks moments of culinary appropriation 
made inevitable by its hierarchical narrative framework. ${ }^{34}$ The "foreign" foods introduced in the novel are strange and overly sensual in the eyes of narrator Jim, Cather's openly stated likeness, and this is an acceptable constant in the world of the novel, even when Jim openly lays claim to other groups' cultural products. ${ }^{35}$ Thus, the narrative structure of the novel and Cather's treatment of food in this sense echoes the ideology espoused by Howellsian realism, in which class divisions are reinforced under the guise of democratic representation. Ultimately, neither Jim nor Cather can shed the authority of narration and transcend his or her subject-position, and Jim's romanticizing of Ántonia's person and culture - and, in turn, his dismissal of her when she does not cohere to his imagined ideal - suggests the drawbacks of an unexamined pluralistic view, such as the elision of structural inequality in favor of embracing and, in some cases, overemphasizing "difference."

\section{The Emotional Consumer}

While specific foods in part serve to identify and romanticize immigrant characters for a privileged readership, thereby stratifying the two, Cather also recognizes culinary engagement as a crucial aspect of identity. Many of Cather's nonfiction and fiction writings both explicitly and implicitly oppose the ideological and sensory limitations imagined for the American public body by the domestic scientists, early home economists, and the imperatives to standardize, mass-produce, and package. Cather states in a 1921 speech, "The Americanization committee worker who persuades an old Bohemian housewife that it better for her to feed her family out of tin cans instead of cooking them a steaming goose for dinner is committing a crime against art." "Art is a matter of enjoyment through the five senses," Cather proclaimed, also in 1921. "Esthetic appreciation begins with the enjoyment of the morning bath. It should include all the activities of life. There is real art in cooking a roast just right, so that it is brown and dripping and odorous and 'saignant." "37 Throughout her life, Cather vocally opposed those who suggested that immigrants discard their traditional eating habits in favor of a homogenized, Americanized cuisine. ${ }^{38}$ This was not only an insult to the quality of immigrant foodways but also, according to Cather, an insult to the free expression of artistic agency. By categorizing cooking as an art form, Cather divorces it from the scientific rigidity and nutritional pragmatism promoted by the domestic scientists and early home economists. ${ }^{39}$

Examining Cather's use of food scenes and food imagery alongside narrative structure in My Antonia brings into sharp focus the novel's relationship to the principles of realism. Although the foods that Cather describes are typical for the immigrants who consume them regularly or are integral to their cultural identity, the foods themselves - and thus the immigrants - are routinely positioned as exotic and at times subhuman. Further, ingesting these foods and participating in immigrants' food practices serve as a means of imaginative arousal for Jim as he builds his own identity in relation to his environment. In 
these scenarios, specific foods - like the immigrants themselves - are utilized as a platform for Jim's exploration of self. However, Cather does allow food scenes to be emotionally generative and less restrictive than would have been supported by food reformers' obsession with measurement and nutrition. These food scenes involve both native and immigrant characters and thus constitute less a statement about the significance of immigrant foodways - although Cather certainly valued them - and more a commentary on the capability of the culinary to function as art and meaningfully shape identity. For certain characters, cooking functions as an impetus for storytelling and the preservation of cultural memory; for others, consumption serves as a catalyst for creativity and even as an outlet for grief. Throughout her fiction and especially in My Ántonia, Cather attaches to food an intensity, an individuality, and an emotive quality that openly opposes the ideology of the domestic scientists and early home economists, both of whom sought to align eating habits with a particularly rigid conception of individual and national identity.

\section{On Mushrooms and Melons}

Jim helps to foreground, very early on, Cather's ongoing tendency to pair consumption and creativity. Having agreed to record their memories of Ántonia, both Jim and the preface's unnamed narrator meet to share the results of their efforts. Although the narrator returns empty-handed, Jim has composed a full manuscript. Before relinquishing his work to the narrator, Jim recounts his writing process: “"Notes? I didn't make any.' He drank all his tea at once and put down the cup. 'I didn't arrange or rearrange. I simply wrote down what of herself and myself and other people Ántonia's name recalls to me. I suppose it hasn't any form. It hasn't any title, either.'"40 Jim's act of consumption, where he drinks his tea "all at once," announces the novel's propensity toward pairing emotion and creative production with ingestion, or the smells and textures of both everyday and "exotic" foods. Jim's composition strategy in this scene aligns with the unmediated, antiliterary, and "true" depiction of life sought after by the realists, just as it reinforces the novel's aesthetic scaffolding, in which food and drink share a kinship with art and creation that proves especially revelatory for the cultural landscape that Cather constructs.

In My Ántonia, the pairing of food and creativity suggests a revision of contemporaneous ideas about the importance of policing one's sensory reactions and experiences. Jim's hurried act of consumption mirrors his chaotic emotional state and internal confusion about his place in the world. Cather depicts Jim as a man ideologically lodged between his past and his future, unsure of how to proceed, needing to procure meaning in the feverish artistic recounting of his relationship to his childhood immigrant friend. Jim's wealthy wife, described as "handsome, energetic, executive," is a product of a materialistic, ordered, precise society; in fact, she seems to be a manifestation of the ideology promoted by the domestic scientists. ${ }^{41}$ However, Jim's imbibing of tea, his cre- 
ation of the manuscript, and the reality of his unhappy marriage all suggest that he is suspicious of - and perhaps even prepared to distance himself from - the restrictive ideologies surrounding the production of the "ideal" citizen. Ultimately, the novel's preface makes clear that Ántonia, her Bohemian family, the Norwegians, the Russians, and other immigrants in the novel have had a profound impact on Jim's maturation and imagination. As Jim ideologically mines his past through the manuscript he presents to readers, the novel highlights alternative ways of conceptualizing personhood and American identity through a widening of what it means to exist as a sensory being in one's surroundings.

However, despite immigrants' formative influence on Jim's identity and their integral role in introducing him to a varied cultural landscape, My Antonia's narrative necessitates Jim's appropriation of certain foods at the expense of immigrant characters, specifically Mrs. Shimerda, the Russians, and at one point Ántonia herself. In other words, Jim is unable to distance himself from his own subject-position as "ideal observer," unconcerned with the power that his narrative authority naturally brings. Despite Cather's useful expanding of what kinds of relationships individuals can form with food, immigrant characters are routinely positioned as odd or foreign precisely through culinary characterization. Jim and his family are often dubious of the Shimerdas' culinary practices, ranging from storing food to table manners, and the narrative remains uncritical in these moments. In fact, although the narrative does occasionally, if subtly, question Jim's judgment, it does not do so in moments where he engages with food, which suggests that Jim's authority is most often exerted in moments of culinary appropriation of foreign foods at the expense of the immigrants themselves.

In one example, Jim recalls that he and his family were "horrified" at how Mrs. Shimerda stored and made bread and devotes an entire paragraph to a description of her unusual and unsanitary practices. Jim writes, "She mixed her dough, we discovered, in an old tin peck-measure. ... When she took the paste out to bake it, she left smears of dough sticking to the sides of the measure . . . and let this residue ferment." 42 Jim's use of the word "discovered" highlights the unpleasantness of the scenario, as though it is something gruesomely happened on. The tone of the paragraph is one of distaste and mild annoyance, which is a quality exhibited in other areas of the novel when Jim refers to the Shimerdas' culinary practices, effectively identifying them as foreign via their unusual eating and cooking habits. Elsewhere, the Burdens contemplate the fact that the Shimerdas are hunting and eating prairie dogs, to which Jim's grandmother responds with "alarm." "43 Jake, the Burdens' farmhand, who delivers the news, "grinned and said [the prairie dogs] belonged to the rat family." 44 Although it is evident the Shimerdas are resorting to such measures due to struggle and poverty, the Burdens cast a distinct shadow of disapproval in how the Bohemian family has chosen to deal with their circumstances.

Jim and his family easily dismiss Mrs. Shimerda, whom Jim at one point 
calls "a conceited, boastful old thing," 45 yet Jim uses a Bohemian food item gifted by Mrs. Shimerda to expand his horizons and sensory experiences. In one of the more memorable scenes in the novel, Mrs. Shimerda gifts Mrs. Burden a small packet of dried Bohemian mushrooms, hoping to extend a taste of her homeland to her American neighbors. Jim's grandmother reacts by stating that because she cannot pinpoint the origin or nature of the food, she is afraid of it. She then discards the package by throwing it into the stove. Jim, on the other hand, decides to try the dried mushrooms; he ingests a small dried chip, though with reserve. Jim then identifies the taste of the mushrooms as an unforgettable sensation, speculating, "They had been gathered, probably, in some deep Bohemian forest." 46 In this scene, Jim uses the mushrooms to open his mind; they transport him to a completely different location and render him worldlier through their sensory power. Jim is willing to use the mushrooms for his own purposes - to grow creatively and expand his imagination - but he is not willing to acknowledge Mrs. Shimerda's role in this expansion. Meanwhile, the narrative lingers on this moment and uses the mushrooms as a springboard for emotional affect, entirely uncritical of Jim's reaction. In this sense, Jim's narrative authority remains unquestioned as he mines the mushrooms for creative and spiritual meaning while pushing Mrs. Shimerda's experiences and reality aside.

The narrative also features two Russian homesteaders-Peter and Pavelwho have been exiled from their home country for the impossible act of feeding a bridal party to wild wolves. Peter, consistently referred to as "Rooshian Peter," is described as having taken on the physical characteristics of a melon: "his rosy face, with its snub nose, set in this fleece, was like a melon among its leaves." ${ }^{47}$ The men's food habits are similarly described as odd; they hoard food in their home, and they extend too much care to the cow they own that supplies them with dairy. At one point, Jim and Ántonia participate in a melon feasta popular food item in Russia with a storied history-in which Peter stands over the melons "brandishing a butcher knife."48 This scene is both thrilling and surreal. Jim's participation in Peter's melon feast allows him to vicariously experience the danger associated with the tale of the Russians' daring escape from wild wolves in their home country without having to confront the impossibility of their status as exiles. Ultimately, Peter and Pavel's story ends in tragedy as Pavel succumbs to illness and Peter is left to wander the earth alone. Jim's participation in the melon feast and Cather's construction of this scene emphasize the thrill and strangeness of the experience while eliding the pain of the Russians' demise. As with the Bohemian mushrooms, Jim uses "ethnic" foods dear to the Russians to stoke his imagination and, by proxy, structure his own identity.

At the same time, as she does by pairing Jim's tea drinking with his creative burst, Cather uses the Russians to establish a connection between consumption and emotion, in the process pushing against the boundaries set by the domestic scientists and home economists about what it meant to eat in terms 
of content and quantity. For Peter especially, the act of consumption is an act of burying grief in one's own bodily functions, as the emotions accompanying extreme grief unapologetically produce the conditions for overeating. In one of the reader's final encounters with the Russians, Peter is pictured burying his grief at Pavel's death in the ritual act of consuming a large quantity of melons. Cather writes, "After all his furniture and his cook-stove and pots and pans had been hauled off by the purchasers, when [Peter's] house was stripped and bare, he sat down on the floor with his clasp-knife and ate all the melons that he had put away for winter." 49 Peter is found "with a dripping beard, surrounded by heaps of melon rinds." ${ }^{50}$ Peter relies on the melons to satiate his emotional needs, as their mystical healing properties help soothe the pain of Pavel's death. Cather presents to the reader an alternative view of consumption than that which was widely understood as "proper." In the novel, consumption-even overconsumption - is presented as a viable way of confronting or subsuming grief, just as in Jim's case consumption is a viable method for working out one's conflicting emotions.

Cather continues to reinforce links between food and creativity, memory, and emotion in the latter parts of the narrative, when the Burdens move into town and Ántonia begins to work as a "hired girl" for the Harlings, the Norwegian family next door. Multiple scenes positively establish the significance of food's emotional potency and its generative value, thereby forging an important link between consumption and identity. On a spontaneous outing in the prairie involving Jim, Ántonia, and three of the other "hired girls" (Lena, Tiny, and Anna), the girls reminisce about their parents' and grandparents' experiences with immigration. Tiny reveals that " My old folks ... have put in twenty acres of rye. It seems like my mother ain't been so homesick, ever since father's raised rye flower for her." ${ }^{51}$ Meanwhile, Anna remarks, "“[My grandmother]'s forgot about this country, and thinks she's home in Norway. She keeps asking mother to take her down to the waterside and the fish market. She craves fish all the time. Whenever I go home I take her canned salmon and mackerel." "552 Tiny and Anna's observations point to the obvious connection between food and memory-how the tastes, smells, textures, and appearances of specific foods can comfort and nourish not just the body but also the mind, even when, in the case of Anna's grandmother, one might be in the presence of an ailing mind. In these scenes especially, ingesting food is ingesting culture-albeit sometimes a mass-produced version of culture. It is also a necessary means of self-preservation. Here, Cather presents alternative ways of conceptualizing the importance of ingestion and one's relationship to food: it isn't simply a pragmatic exercise but, rather, an emotional one.

Strikingly, Ántonia becomes an exemplar of the immigrant women that Cather so admired during her own childhood in Red Cloud, Nebraska, specifically through the act of food preparation. Jim recalls, "While we sat in the kitchen waiting for the cookies to bake or the taffy to cool, Nina [Harling] used to coax Ántonia to tell her stories_-about the calf that broke its leg, or how Yulka 
saved her little turkeys from drowning in the freshet, or about old Christmases and weddings in Bohemia." ${ }^{53}$ Cather depicts a unique creative process - a window to culture and memory inspired by the act of culinary creation - which is in many ways emblematic of her own youth. Cather purposefully compares the act of cooking to the act of storytelling, both as practices that are necessary to the preservation and reaffirmation of culture, history, and heritage. Thus, Cather highlights both cooking and storytelling as valuable components of a healthy and vibrant society and, in the process, reaffirms the relationship between eating and emotion.

The connections between food and creativity, language, and culture are brought home in the novel's concluding scenes, when Jim, having finally reconnected with Ántonia after decades of estrangement, visits her new family farm in Nebraska. Ántonia Shimerda - now Ántonia Cuzak - is married with many children and owns a sprawling farmland that includes several orchards and abundant livestock. Ántonia's farmland yields cherries, gooseberries, currants, apples, grapes, and contains a rye field, whereas her family's fruit cave holds barrels of dill pickles, chopped pickles, and pickled watermelon rinds. During his visit, Jim slowly becomes acquainted with Ántonia's many children, all of whom have learned Bohemian as their primary language, thereby resisting full assimilation. In these scenes, various foods with their sensory potency-some Euro-ethnic staples and others not-are presented as a gateway to creativity, to mental and physical sustainability. Not unlike Mrs. Shimerda's presentation of the mushrooms to Jim's grandmother, Ántonia, swelling with pride, leads Jim to the family's fruit cave. There, three of Ántonia's young children-Nina, Jan, and Lucie - shyly point out to Jim glass jars and "[trace] on the glass with their finger-tips the outline of the cherries and strawberries and crab-apples within, trying by a blissful expression of countenance to give [him] some idea of their deliciousness." ${ }^{54}$ Although the children are otherwise quiet and reserved, in this moment they present to Jim a snippet of their personalities and their cultural inheritance linked to food preservation and preparation, all despite not being able to fully communicate in English. In other words, the fruit within the jars - and perhaps the promise of its gustatory satisfaction - inspires in the children a moment of bravery that allows them to communicate wordlessly with Jim. In this instance, they communicate through food more than they could have possibly communicated through language.

Despite this rather heartwarming scene, Jim also claims ownership of the kolache - a Czech pastry - during his final visit with Ántonia and her family. In this scenario, Antonia's sons attempt to extend to Jim a piece of their cultural and culinary heritage, noting with pride their intimate experiences with the delicious pastry, made with fresh plums, something that Americans "don't have." ${ }_{55}$ Jim responds by confidently stating to Leo, one of Ántonia's sons who is skeptical of the exchange, "You think I don't know what kolaches are, eh? You're mistaken, young man." "J6 Jim goes on to assert that his experience with kolaches far exceeds that of Ántonia's own children, as he consumed them prior 
to their birth. In this scenario, Jim adopts a tone of superiority and paternalism that elides the boys' own cultural legacy. Instead of allowing Ántonia's young sons the privilege of extending to a white "foreigner" intimate knowledge of their own culinary heritage, Jim shuts down this moment of cultural exchange by adopting the kolaches as his own. Jim's decision to claim ownership of the kolache strips the boys of the opportunity to share their unique history, and, in the process, Jim claims ownership of Ántonia's culture and cuisine. Meanwhile, the narrative does not critique Jim's arrogance in this scene; in fact, it is the subtle authority inherent in the narrative's hierarchical structure, stratifying the observer and the observed, that makes this scene and its implications possible.

\section{Consumption and Creation: A Dual Conclusion}

These are by no means the only scenes in which food appears in My Antonia, but even these instances make clear that Cather closely links the act of consumption and food preparation with creative invention throughout her work. This pairing is significant in that it divorces the act of consumption from rigid, middle-class ideas about nutrition, scientific principles, and, thus, the formulation of a "productive," ordered, national body - one that must inevitably be "native" and white. Thus, characters - both immigrant and American - can achieve belonging and citizenship through reconceived notions of what it means to ingest and consume the surrounding world. At the same time, My Ántonia presents a narrator that cannot be divorced from his privileged reality, and neither can Cather herself. Her desire to "get inside the skins" of immigrant women as they cook suggests that Cather - and her novel - are aware of the joys and discoveries to be found in diverse culinary practices and experiences but perhaps signal a slightly less developed understanding of the boundaries that must accompany such desires. My Ántonia adopts realism's focus on narrative authority just as it envisions a reality in which such emphasis on productivity and the "ideal" citizen can finally be erased.

\section{Notes}

1. Willa Cather, interview with the Philadelphia Record, August 10, 1913, quoted in Willa Cather in Person: Interviews, Speeches, and Letters, ed. L. Brent Bohlke (Lincoln: University of Nebraska Press, 1986), 10.

2. Michael Davitt Bell, The Problem of American Literary Realism: Studies in the Cultural History of a Literary Idea (Chicago: University of Chicago Press, 1993), 6.

3. Bell, The Problem of American Literary Realism, 73.

4. Bell, The Problem of American Literary Realism, 32.

5. Laura Shapiro, Perfection Salad: Women and Cooking at the Turn of the Century (New York: Farrar, Straus, and Giroux, 1986), 5.

6. Willa Cather, "William Dean Howells," Nebraska State Journal, July 14, 1895, quoted in Cather: Stories, Poems, and Other Writings, ed. Sharon O'Brien (New York: Library of America, 1992), 892.

7. Cree LaFavour "The Edible Book: White Female Pleasure and Novel Reading," in Culinary Aesthetics and Practices in Nineteenth-Century American Literature (New York: Palgrave Macmillan, 2008), 146.

8. Daniel H. Borus, Writing Realism: Howells, James, and Norris in the Mass Market (Chapel Hill: University of North Carolina Press, 1989), 4. 
9. See William Dean Howells, Criticism and Fiction (New York: Harper and Brothers, 1892), where he writes that "the time is coming, I hope, when each new author, each new artist, will be considered, not in his proportion to any other author or artist, but in his relation to the human nature, known to us all, which it is his privilege, his high duty, to interpret" (8).

10. Amy Kaplan, The Social Construction of American Realism (Chicago: University of Chicago Press, 1988), 46.

11. Sharon O'Brien, "Possession and Publication: Willa Cather's Struggle to Save My Ántonia," Studies in the Novel 45, no. 3 (2013): 466.

12. Katharina Vester, A Taste of Power: Food and American Identities (Berkeley: University of California Press, 2015), 3.

13. Mary J. Lincoln, Mrs. Lincoln's Boston Cook Book: What to Do and What Not to Do in Cooking (Boston: Roberts Brothers, 1884), viii.

14. Fannie Farmer, The Boston Cooking-School Cook Book (Boston: Little, Brown, 1896), xi.

15. Farmer, The Boston Cooking-School Cook Book, xiv.

16. Farmer, The Boston Cooking-School Cook Book, 67.

17. Farmer, The Boston Cooking-School Cook Book, 506-7.

18. Shapiro, Perfection Salad, 112.

19. Shapiro, Perfection Salad, 4.

20. Carolyn M. Goldstein, Creating Consumers: Home Economists in Twentieth-Century America (Chapel Hill: University of North Carolina Press, 2012), 41-42.

21. Jennifer Jensen Wallach, How America Eats: A Social History of U.S. Food and Culture (Lanham, MD: Rowman \& Littlefield, 2013), 134.

22. Wallach, How America Eats, 126-27.

23. Goldstein, Creating Consumers, 3.

24. Willa Cather, The Kingdom of Art: Willa Cather's First Principles and Critical Statements, ed. Bernice Slote (Lincoln: University of Nebraska Press, 1967), 31.

25. For a useful positioning of Cather as a modernist, see Stephanie Thompson, Influencing America's Tastes: Realism in the Works of Wharton, Cather \& Hurst (Gainesville: University Press of Florida, 2002), 126-28.

26. For a discussion of Cather's "antiliterary" strain, see Paul Petrie, "“There Must Be Something Wonderful Coming': Social Purpose and Romantic Idealism in Willa Cather's 'Behind the Singer Tower," American Literary Realism 33, no. 2 (2001): 110-22. For a discussion of visual accuracy in Cather's work, see Janice P. Stout, "Seeing and Believing: Willa Cather's Realism," American Literary Realism 33, no. 2 (2001): 168-80. Despite Stout's interest in finding strands of realism in Cather's work, she points out that "Cather regularly eludes the critical nets in which we seek to capture her" (168).

27. Nancy Glazener, Reading for Realism: The History of a US Literary Institution, 18501910 (Durham, NC: Duke University Press, 1997), 17.

28. More readings of Cather and realism have emerged in recent decades, such as a 2001 special edition of American Literary Realism that is entirely devoted to examining the relationship of realism to Cather's body of work. This issue, notes Susan J. Rosowski in her introduction "Willa Cather and American Literary Realism," American Literary Realism 33, no. 2, Special Issue: Willa Cather (2001): 95-98, explores Cather's “[engagement] with the literary schools of her time" (97). The essays within it link Cather's journalism career to her relationship with realism and examine the strands of realism in her novels from a structural and aesthetic perspective.

More recently, several scholars have attempted to trace Cather's literary techniques and influences to Howells. In "William to Willa, Courtesy of Sarah: Cather, Jewett, and Howellsian Principles," American Literary Realism 38, no. 2 (Winter 2006): 145-59, John J. Murphy makes a compelling argument for Sarah Orne Jewett as a link between Cather and Howells. According to Murphy, Jewett herself was "a product of the Atlantic Monthly" (151), where Howells was editor and able to nurture and shape the direction of her work. Thus, Murphy suggests, the fact that Cather was so influenced by Jewett suggests a viable connection between Cather and Howells, especially given that Jewett's recommendations to Cather were often in line with Howells' literary philosophy.

29. See James Woodress, Willa Cather: Her Life and Art (New York: Pegasus, 1970), for details about Cather's relationship to Howells and his novels.

30. Willa Cather, "The Novel Démeublé," The New Republic 30 (April 12, 1922): 5-6.

31. In "The Novel Démeublé," Cather also argues that the novel has long been "over-furnished" (n.p.) and suggests that to create literature in its ideal form, one must "throw all the furniture out of the window" (n.p.). In other words, Cather opposes the trend of cataloging in fiction, of recording the mundane without meaning - a practice that she sees as unforgivably Howellsian. Yet Cather's treatise also shows that she was preoccupied with realism and its lingering grasp on literary culture. She writes, "There are hopeful signs that some of the younger writers are trying to break away from verisimilitude . . . to interpret imaginatively the material and social investiture of their characters; to present their scene by suggestion rather than enumeration" (n.p.). This excerpt reflects realism's steady grasp: despite Cather's opposition to the characteristics of realism (namely, verisimilitude and enumeration), the fact that she is "hopeful" about young writers "trying" to 


\section{Stephanie Tsank}

evade them suggests a literary future that has not yet broken free of its past.

32. Many contemporaneous reviewers of My Ántonia, such as Randolph Bourne, H. L. Mencken, and others, praised the novel for its "realness." As Sharon O'Brien documents in "Possession and Publication," "Reviewers connected Cather's realism with her decision to tell, and tell accurately, the foundational American story of immigration and pioneer renew" (472).

33. See Bernice Slote, The Kingdom of Art, and Susan J. Rosowski, The Voyage Perilous: Willa Cather's Romanticism (Lincoln: University of Nebraska Press, 1986), for opposing arguments suggesting that the novel's structure, in which Jim pens the manuscript of My Antonia in a creative burst, suggests a romantic impulse - that of Jim remembering his past, idealizing his (and in some cases Cather's own) youthful interactions with the various immigrant families populating the Nebraskan plains.

34. See Andrew Jewell, “A Crime against Art': My Ántonia, Food, and Cather's Anti-Americanization Argument," Willa Cather Newsletter and Review 54, no. 2 (2010): 72-76. Jewell draws connections between Cather and Randolph Bourne, a prominent pluralist who was active during the early twentieth century. I agree with Jewell's assessment that much of Cather's fiction involving immigrants advocates for a pluralist view in opposition to the melting pot ideology that was extremely popular during the time. However, Jim's position of power as white male narrator and cultural connoisseur remains unexamined by both Jim's self-reflexive narration and the novel's own logic.

35. In her interviews, Cather compares herself to Jim; see Bohlke, Willa Cather in Person, 44. Meanwhile, in the "Introduction" to the Penguin edition of My Ántonia, John J. Murphy warns against the dangers of conflating Jim and Cather. While I take his point, for the purposes of my argument it is useful to consider Cather's parallels to Jim because I am thinking about how both author and character share many of the same markers of privilege that inform the narrative's structure and how both Jim and Cather appeal to the same audience. Likewise, it is important to note that there are moments where the narrative is critical of Jim's myopic perspective or his limitations, such as in his choice to marry a woman completely unsuited to him.

36. Bohlke, Willa Cather in Person, 147.

37. Bohlke, Willa Cather in Person, 47.

38. In "A Crime against Art," Jewell elaborates on Cather's response to the domestic science movement's efforts to homogenize American cuisine, focusing on Cather's insertion of new foods into the American literary and cultural landscape. Jewell argues that "by introducing kolache made with home-canned plums to English-language readers, [Cather] forcefully inserts a 'foreign,' handcrafted food and therefore challenges the widespread attempts to homogenize American cuisine" (74). I agree with Jewell's interpretation with the caveat that in My Antonia, Jim's response to the kolache serves as an appropriation of the "foreign" food despite Cather's introduction of it into the culinary scene at large.

39. Certainly, Cather was not alone in her view: as Donna Gabaccia explains in We Are What We Eat: Ethnic Food and the Making of Americans (Cambridge, MA: Harvard University Press, 1998), immigrants at the turn of the century tended to resist the culinary homogeneity promoted by the domestic scientists, early home economists, and the corporatization and mass production of food. While some ethnic enclaves succumbed to a more Americanized cuisine, many immigrants were culturally conservative and remained isolated from new developments in food production.

40. Willa Cather, My Ántonia, ed. John J. Murphy (New York: Penguin Books, 1994), 6.

41. Jewell extends this argument further in " A Crime against Art," by identifying the public kitchen reformer named Florence Burden, who lived in New York City while Cather was there composing My Antonia, as possible inspiration for Jim's wife (74).

42. Cather, My Ántonia, 29.

43. Cather, My Ántonia, 58.

44. Cather, My Ántonia, 59.

45. Cather, My Ántonia, 73.

46. Cather, My Ántonia, 65.

47. Cather, My Ántonia, 31.

48. Cather, My Ántonia, 31.

49. Cather, My Ántonia, 50.

50. Cather, My Ántonia, 50.

51. Cather, My Ántonia, 182.

52. Cather, My Ántonia, 182.

53. Cather, My Ántonia, 138.

54. Cather, My Ántonia, 251-52.

55. Cather, My Ántonia, 252.

56. Cather, My Ántonia, 252. 